\title{
EFFECTS OF Gmelinaarborea, Roxb LEAVES ON GROWTH PERFORMANCE OF Coturnixcoturnix japonica, Temmick.
}

\author{
Asolo Chioma Helen \\ asohelecy@gmail.com \\ Okeke John Joseph \\ Okekejaja@yahoo.com
}

Okafor Ukamaka Elizabeth

amakaokafor2011@gmail.com

Ezeanekwu Raymond Orji ${ }^{2}$

ezeanekwuraymondorji@gmail.com

\author{
${ }^{1}$ Department of Zoology, Faculty of Biosciences, NnamdiAzikiwe University, Awka, Nigeria. \\ Department of Microbiology, Faculty of Natural sciences, Chukwuemeka Odimegwu Ojukwu University, Uli, \\ Nigeria. \\ DOI: $10.31364 / S C I R J / v 8 . i 2.2020 . P 0220748$ \\ http://dx.doi.org/10.31364/SCIRJ/v8.i2.2020.P0220748
}

\begin{abstract}
Humans and livestock are competing for plant proteins which are shifting the dependency of human on plants to that of animals for protein despite insufficiency of animal protein. For reduction in the price of animal products there is need to use plant supplement(s) which can encourage higher growth rate or improve the quality of the animal products. One of such ingredients is Gmelina arborea leaf meal, a product of Gmelina arborea tree which is not in competition with man's dietary needs. But despite the abundance and availability of this resource in Nigeria, many studies have not been carried out on its nutritional value and use in poultry feeding, especially in Japanese quail. Based on the above, this research work was conducted to evaluate the effects of varying inclusion levels of Gmelina arborea Meal on growth of Japanese quail birds (Coturnix coturnix japonica).This study was carried out to conduct a thirty-six weeks feeding trial to determine the effect of feeding varying levels of Gmelina arborea leaf Meal on growth performance, using two (2) weeks old Japanese quail (Coturnix coturnix japonica). Ninety-six birds were allocated to four dietary treatment groups with three (3) replicates of eight (8) birds each in a completely randomized design experiment with feeding ratio of Control (A) containing $0 \mathrm{~g} / \mathrm{kg} ; \mathrm{B}, 50 \mathrm{~g} / \mathrm{kg} ; \mathrm{C}, 100 \mathrm{~g} / \mathrm{kg}$ and $\mathrm{D}, 150 \mathrm{~g} / \mathrm{kg}$ of air-dried and ground Gmelina arborea. Feed and water were provided throughout the experimental period. Weight gain and feed utilization indices were the response criteria that were monitored, recorded and subjected to Statistical analysis. There were significant difference $(\mathrm{P}<0.05)$ observed for mean weight gain, percentage weight gain, specific growth rate, feed intake, feed conversion ratio, feed efficiency ratio, protein efficiency ratio. From this study, quail birds fed $\mathrm{C}(0 \mathrm{~g} / \mathrm{Kg})$ followed by those fed $\mathrm{T}_{1},(50 \mathrm{~g} / \mathrm{kg}) \mathrm{gave}$ better results on the birds showing that Gmelinaarborea is dosage and time dependent and can be recommended in Japanese quail diets in that quantity but shorter duration.
\end{abstract}

Index Terms- inclusion, growth, treatment, feed, quails, weight

\section{Introduction}

Some of the major constraints in poultry production are irregular supply of conventional feed-stuffs especially protein feedstuff and disproportionate high cost of feed. Efforts should therefore be directed towards exploiting feed resources that are cheap, available and not in direct use by humans and other industrial users (1). The high price of livestock products in Nigeria is associated with high cost of feed ingredients. For reduction in the price of animal products there is need to use plant supplement(s) which can encourage higher growth rate or improve the quality of the animal products (2). The potential of leaf meals from these tropical trees and shrubs to yield relatively higher levels of crude protein and minerals, and lower crude fiber levels than tropical grasses has also been recognized $(\mathbf{3}, \mathbf{4}, \mathbf{5}$ and 6). Despite the amount of research carried out with nonconventional feeding materials, which could have a major impact on livestock production, they continue to be unused, 
underdeveloped or underutilized. A critical factor in this regard has been the lack of proper understanding of the nutritional principles underlying their utilization (7).

\section{Materials and Methods}

This thirty-six weeks feeding trail was conducted to determine the effect of feeding varying levels of inclusion of Gmelina arborea leaf meal on growth using ninety-six, (2) weeks old Japanese quail (Coturnix coturnix japonica)(both females and males) at Nnamdi Azikiwe University, Awka, Anambra State, Nigeria.

Study Design: Prospective open observational study

Study Duration: March 2019 - November 2019.

Sample size: Ninety-six, (2) weeks old Japanese quail (Coturnixcoturnix japonica) (both females and males).

Sample size calculation: Ninety-six birds were allocated to four dietary treatment groups with three (3) replicates of eight (8) birds each in a completely randomized design experiment with feeding ratio of Control (A); Treatment $1(\mathrm{~B})$; Treatment 2 (C) and Treatment 3 (D).

Subject \& selection method: .The birds were allocated to four dietary treatment groups with three (3) replicates of eight (8) birds each in the ratio of three (3) females to one (1) male, in a completely randomized design experiment with the following feeding trial inclusion levels;

A (Control) containing $0 \mathrm{~g} / \mathrm{kg}$;

B containing $50 \mathrm{~g} / \mathrm{kg}$;

C containing $100 \mathrm{~g} / \mathrm{kg}$ and

D containing $150 \mathrm{~g} / \mathrm{kg}$ of room dried and ground Gmelina arborea leaf meal (GLM) in that order.

Inclusive criteria:

1. Initial weight of the birds

2. Final weight of the birds

3. Mean weekly weight gain of the birds

4. Percentage weight gain (PWG)

5. Specific growth ratio (SGR)

6. Feed intake by the birds

7. Feed conversion ratio (FCR)

8. Feed Efficiency Ratio (FER)

9. Protein Efficiency Ratio (PER)

\section{Exclusive criteria:}
1. Fertility
2. Hatchability
3. Egg production

Procedure methodology:

The Gmelina arborea leaves were collected from Awka and were washed, air-dried and milled. A total of ninety-six (96) Japanese quail birds were used for the study. This study lasted for 36 weeks. The experimental cage was the colony closed cage housing system. Each of the 4 tiers had 3 partitions representing 4 treatments with 3 replicates respectively. The animals were allocated into four groups with three replicates of eight birds each with the ratio of 1 male to 3 females (8) on live weights. The housing groups were based on the level of Gmelina arborea trail Meals inclusions of A- 0g/kg, B- 50g/kg, C- $100 \mathrm{~g} / \mathrm{kg}$ and D$150 \mathrm{~g} / \mathrm{kg}$. The feeds used during the study were formulated feeds with Gmelina arborea leaf meal. Weight gain (WG), Percentage weight gain (PWG), Specific growth ratio (SGR)(9), Feed conversion ratio (FCR), Feed Efficiency Ratio (FER) Protein Efficiency Ratio (PER)(10)were the response criteria that were monitored, recorded and subjected to Anova and T-test.. The feed with different levels of inclusion of Gmelina arborea were analyzed for proximate composition(11) for Moisture Content (MC), Crude Protein (CP), Crude Fat (CF), Total Ash (TA), Crude fibre (F) and Carbohydrates (C). Phytochemical tests for the presence or absence of alkaloid, saponnin, flavanoid, tannin and steroid were carried out on the methanolic extract of Gmelina arborea leaves used in feeding the quails using the procedure outlined(12).

\section{Statistical Analysis}

The data of weight gain were subjected to Analysis Of Variance (ANOVA) using SPSS (13). The mean percentage weight gain, specific growth rate and feed utilization indices were subjected to a T- test using the SPSS Statistical Package version 20. The least significant difference (LSD) was used to separate mean significant differences between treatments at the 5\% significant level.

\section{Results}

Table 1; Feed Formulation for Quail birds

\begin{tabular}{lclll}
\hline Ingredients & $\mathrm{A}(0 \mathrm{~g} / \mathrm{kg})$ & $\begin{array}{l}\mathrm{B}(50 \mathrm{~g} / \mathrm{kg}) \\
(\mathrm{Kg})\end{array}$ & $\mathrm{C}(100 \mathrm{~g} / \mathrm{kg})$ & $\mathrm{D}(150 \mathrm{~g} / \mathrm{kg})$ \\
\hline G.arborea & 0.00 & 5.00 & 10.00 & 15.00 \\
Maize & 45.02 & 45.02 & 45.02 & 45.02 \\
Wheat offal & 10.00 & 10.00 & 10.00 & 10.00 \\
Soya Beans & 11.76 & 11.76 & 11.76 & 11.76 \\
\hline \multicolumn{5}{c}{ www.scirj.org } \\
\end{tabular}




\begin{tabular}{lcccc}
\hline Groundnut Cake & 23.52 & 23.52 & 23.52 & 23.52 \\
Bone Meal & 3.00 & 3.00 & 3.00 & 3.00 \\
Limestone & 6.00 & 6.00 & 6.00 & 6.00 \\
Salt & 0.20 & 0.20 & 0.20 & 0.20 \\
Methionine & 0.15 & 0.15 & 0.15 & 0.15 \\
Lysine & 0.10 & 0.10 & 0.10 & 0.10 \\
Premix & 0.25 & 0.25 & 0.25 & 0.25 \\
\hline
\end{tabular}

From Table 2, the result of the phytochemical composition of the Gmelinaarborea showed the presence of flavonoid, tannin, saponins, alkaloid, phenol and steroid. The tannin, phenol and saponin are strongly present, flavanoid, steroid and alkaloid are moderately present.

Table 2: Phytochemical composition of Gmelina arborea.

\begin{tabular}{|l|c|}
\hline $\begin{array}{l}\text { Phytochemical } \\
\text { parameter }\end{array}$ & $\begin{array}{l}\text { Qualitative } \\
\text { results }\end{array}$ \\
\hline Flavonoid & + \\
\hline Tannin & ++ \\
\hline Steroid & + \\
\hline Saponin & ++ \\
\hline Phenol & ++ \\
\hline Alkaloid & + \\
\hline
\end{tabular}

Key: + = present; ++ = Strongly present

From Table 3 below, feed with different inclusion levels $(0 \mathrm{~g} / \mathrm{kg}, 50 \mathrm{~g} / \mathrm{kg}, 100 \mathrm{~g} / \mathrm{kg}, 150 \mathrm{~g} / \mathrm{kg})$ of Gmelina arborea leaf meal had values of moisture, crude fat, ash and protein contents that were increasing with increase of the inclusion levels. Treatments with different inclusion levels $(0 \mathrm{~g} / \mathrm{kg}, 50 \mathrm{~g} / \mathrm{kg}, 100 \mathrm{~g} / \mathrm{kg}, 150 \mathrm{~g} / \mathrm{kg})$ of Gmelina arborea leaf meal had the values of carbohydrate and crude fibre contents in the decreasing order.

Table 3: Nutrient composition of the feed with varying levels of Gmelina arborea leaf meal

\begin{tabular}{lrrrr}
\hline Analysis & $\mathrm{A}(0 \mathrm{~g} / \mathrm{kg})$ & $\mathrm{B}(50 \mathrm{~g} / \mathrm{kg})$ & $\mathrm{C}(100 \mathrm{~g} / \mathrm{kg})$ & $\mathrm{D}(150 \mathrm{~g} / \mathrm{kg})$ \\
& & 4.20 & 4.70 & 4.90 \\
Moisture & 3.70 & 5.60 & 5.80 & 6.10 \\
Crude Fat & 4.80 & 12.80 & 13.40 & 13.70 \\
Ash & 10.50 & 17.80 & 18.40 & 18.90 \\
Protein & 17.30 & 6.90 & 6.10 & 5.40 \\
Crude Fibre & 7.70 & 52.70 & 51.60 & 50.90 \\
Carbohydrate & 55.90 & 1.88 & 1.86 & 1.79 \\
$\mathrm{Ca} / \mathrm{P}$ & 1.68 & 0.05 & 0.06 & 0.06 \\
$\mathrm{Na} / \mathrm{P}$ & 0.04 & & & \\
\hline
\end{tabular}

From Table 4 below, the mean weight gains of Quail birds subjected to different dietary treatments showed high significant difference $(\mathrm{P}<0.05)$ across each dietary treatments. There was a significant difference $(\mathrm{P}<0.05)$ in the percentage weight gain, specific growth rate, feed intake, feed conversion ratio, feed efficiency ratio and protein efficiency ratio of the quails among each dietary treatments.

Table 4; Effect of Gmelinaa rborea leaf Meal on Growth Performance Indices of Quails

\begin{tabular}{lcccc}
\hline Parameters & $\mathrm{A}(0 \mathrm{~g} / \mathrm{kg})$ & $\mathrm{B}(50 \mathrm{~g} / \mathrm{kg})$ & $\mathrm{C}(100 \mathrm{~g} / \mathrm{kg})$ & $\mathrm{D}(150 \mathrm{~g} / \mathrm{kg})$ \\
\hline Initial weight $(\mathrm{g})$ & $57.81 \pm 0.26$ & $57.58 \pm 0.88$ & $57.94 \pm 0.80$ & $57.88 \pm 0.81$ \\
Final weight $(\mathrm{g})$ & $168.10 \pm 1.08^{\mathrm{a}}$ & $160.69 \pm 5.26^{\mathrm{a}}$ & $157.13 \pm 7.83^{\mathrm{a}}$ & $153.10 \pm 2.83^{\mathrm{a}}$ \\
Weight gain $(\mathrm{g})$ & $110.29 \pm 1.16^{\mathrm{b}}$ & $103.11 \pm 4.24^{\mathrm{b}}$ & $99.19 \pm 8.53^{\mathrm{b}}$ & $95.22 \pm 2.93^{\mathrm{b}}$ \\
Percentage Growth Rate $(\%)$ & $190.78 \pm 2.41^{\mathrm{c}}$ & $175.82 \pm 8.46^{\mathrm{c}}$ & $171.19 \pm 17.19^{\mathrm{c}}$ & $164.51 \pm 6.22^{\mathrm{c}}$ \\
Specific growth rate & $0.184 \pm 0.003^{\mathrm{d}}$ & $0.178 \pm 0.004^{\mathrm{d}}$ & $0.172 \pm 0.011^{\mathrm{d}}$ & $0.167 \pm 0.004^{\mathrm{d}}$ \\
$\begin{array}{l}\text { Total feed intake(g) } \\
\text { Average daily feed intake }\end{array}$ & $3187.23 \pm 1.47^{\mathrm{a}}$ & $3177.59 \pm 2.43^{\mathrm{a}}$ & $3162.68 \pm 3.19^{\mathrm{a}}$ & $3166.51 \pm 1.96^{\mathrm{a}}$ \\
(g/quail/wk) & $140.55 \pm 0.12^{\mathrm{b}}$ & $139.79 \pm 0.52^{\mathrm{b}}$ & $139.65 \pm 0.67^{\mathrm{b}}$ & $139.54 \pm 0.28^{\mathrm{b}}$ \\
Feed conversion ratio & $28.90 \pm 0.08^{\mathrm{c}}$ & $30.82 \pm 0.12^{\mathrm{c}}$ & $31.89 \pm 0.36^{\mathrm{c}}$ & $33.25 \pm 0.18^{\mathrm{c}}$ \\
\hline
\end{tabular}




$\begin{array}{lllll}\text { Feed efficiency ratio } & 0.034 \pm 0.002^{\mathrm{d}} & 0.032 \pm 0.005^{\mathrm{d}} & 0.031 \pm 0.012^{\mathrm{d}} & 0.030 \pm 0.003^{\mathrm{d}} \\ \text { Protein efficiency ratio } & 6.375 \pm 0.072^{\mathrm{e}} & 5.793 \pm 0.232^{\mathrm{e}} & 5.391 \pm 0.464^{\mathrm{e}} & 5.038 \pm 0.158^{\mathrm{e}}\end{array}$

a, b, c, d,e; Means with same superscript on the same row differ, significantly $(\mathrm{P}<0.05)$.

\section{Discussion}

In table 3, the highest carbohydrate value of $0 \mathrm{~g} / \mathrm{kg}(55.90 \%)$ of Gmelina arborea leaf meal followed by the $50 \mathrm{~g} / \mathrm{kg}(52.70 \%)$ of Gmelinaarborea leaf meal is not surprising with the weight gain of the animals in those treatment in that concurs with carbohydrates being the primary energy source in the diet which agrees with the report that feeds with higher energy content results to higher growth rate in animals (10). The feed with $150 \mathrm{~g} / \mathrm{kg}$ of Gmelina arborea leaf meal reveals the highest values for ash $(13.70 \%)$, crude fat $(6.10 \%)$ and crude protein $(18.90 \%)$. The crude protein values are in line with the recommended $18 \%$ crude protein (14) and lower than $20 \%$ crude protein recommendation (15 and 16), for production period of quail birds but are higher than the crude protein (17\%) recommendation (17). The higher crude protein content with increasing inclusion levels is not surprising due to the reports that the protein content of Gmelina arborea leaf meal is high thus Gmelina arborea leaf meal may be an important source of dietary protein for both human and livestock judging from its proximate composition (5,7 and 18). Also the control treatment of $0 \mathrm{~g} / \mathrm{kg}$ of Gmelina arborea leaf meal had the highest crude fibre and carbohydrates $(7.70 \%$ and $55.90 \%$ respectively). The crude fibre of $0 \mathrm{~g} / \mathrm{kg}$ of Gmelina arborea leaf meal being higher than other treatments was in line with the report that Gmelina arborea leaf meal contain lower level of crude fibre (5.00\%) (18). The fibre content shows substantial amount of fibre which showed that they can help in keeping the digestive system healthy and functioning properly. Crude fiber is part of food that aids and speeds up the excretion of waste and toxins from the body preventing them from sitting in the intestine or bowel for too long which could cause a build up and lead to several diseases (19). This could have attributed to lower and better food conversion ratio of the birds in $0 \mathrm{~g} / \mathrm{kg}$ and $50 \mathrm{~g} / \mathrm{kg}$ treatments and higher nutrient retention which resulted to weight gain as opined that weight gain is a function of degree of nutrient retention (20).

In this study, result of the phytochemical analyses of the Gmelina arborea leaf meal showed the presence of flavonoid, saponins, alkaloid, phenol and steroid with tannin, phenol and Saponin strongly present, flavanoid, steroid and alkaloid moderately present. This concur with the findings that revealed condensed quantity of tannin and other anti-nutritional substances in their biomass affect the optimal utilization by animals (18 and 21). This is in line with the report which also revealed the presence of tannin, alkaloid, saponin, flavonoid and steroid depicting potential toxicity of the feed resources, thereby they adopted in their study that air-drying did not reduce the nutritive values but reduced effect of the anti-nutritional factors (ANF's)(22).This is also in line with the findings which reported that Gmelina arborea is rich in phenol, saponin, alkaloid, tannis, flavonoid and steroid content revealing that it is appropriate to define that the presence of such phytochemicals which make Gmelina arborea leaf meal a potential plant for various pharmaceutical and medical purposes(23). All these could have attributed to the healthy status of the birds throughout the study though it was observed that four birds died from the control diet. This mortality was not associated to the dietary treatment of Gmelina arborea leaf meal, so lack of mortality among the quail layers fed air-dried Gmelina arborea leaf meal confirms that air-drying was effective in detoxifying antinutritional constituents to a certain safety level. This study agrees with the report that in animals a $\mathrm{Ca} / \mathrm{P}$ ratio above 2.0 helps to increase the absorption of Calcium in the small intestine (24). Food is considered "good", if the ratio $\mathrm{Ca} / \mathrm{P}>1$ and "poor" if $\mathrm{Ca} / \mathrm{P}<0.05$ while $\mathrm{Na} / \mathrm{P}$ ratio is 0.06 as the $\mathrm{Ca} / \mathrm{P}$ values for all the treatments were all greater than $1(\mathrm{Ca} / \mathrm{P}>1)$ and their $\mathrm{Na} / \mathrm{P}$ were equal and less than $0.06(\mathbf{2 4})$ as seen in Table 3.

\section{Mean weekly weight increase}

The weekly mean weight gain of quail which was presented in Table 4 , revealed that there is significant difference $(\mathrm{P}<0.05)$ among the dietary treatments which could be due to effect of Gmelina arborea leaf meal levels on the utilization of the diet reducing absorption of nutrients. It was observed that Quails fed with $0 \mathrm{~g} / \mathrm{kg}$ Gmelina arborea leaf meal had the highest mean weight from week 1 to week 5 while those fed with $50 \mathrm{~g} / \mathrm{kg}\left(\mathrm{T}_{1}\right)$ Gmelina arborea leaf meal took the lead from week 6 to 12 . Then Quails fed with $0 \mathrm{~g} / \mathrm{kg}$ Gmelinaarborea leaf meal had the highest mean weight from week 13 to 36 , thereby having the highest mean weight gain with the value of $110.29 \pm 1.16$, followed by $50 \mathrm{~g} / \mathrm{kg}, 100 \mathrm{~g} / \mathrm{kg}$ and $150 \mathrm{~g} / \mathrm{kg}$ with values of $103.11 \pm 4.24,99.19 \pm$ 8.53and 95.22 2.93 respectively reflecting that the Gmelina arborea leaf meal usage could be dosage and time dependent. This result of the weight gain agrees with many works already done with feeding trials of Japanese quail birds; that reported significant different $(\mathrm{P}<0.05)$ on quail fed different protein levels $(16 \%, 18 \%, 20 \%, 22 \%)(\mathbf{1 5})$.The body weight gain values were higher for birds on treatment A $(0 \mathrm{~g} / \mathrm{kg})$ of Gmelina arborea leaf meal) and then decreased with increasing levels of Gmelina arborea leaf meal, thereby showing significant difference $(\mathrm{P}<0.05)$. But the reduction in weight of quails fed inclusions of G.arborea leaf meal is in line with the findings that G.arborea leaf meal had been proved to possess anti-diabetic, anti-microbial activities (23) and also with the fact that the favourable attributes of spices can be masked when they are used in large proportions where the effect of inherent antinutritional factor like tannin and saponin become pronounced(25). These antinutritional factors have been reported to affect utilization of nutrients and depress growth (26). These may be the reasons in weight loss among the birds fed the dietary levels of G.arborea above the $50 \mathrm{~g} / \mathrm{kg}$ level.

\section{Percentage weight gain}

From table 4, the percentage weight gain of quail birds fed with varying levels of Gmelina arborea leaf meal for 36 weeks shows that there is strong significant difference $(\mathrm{P}<0.05)$. It showed that those fed with $0 \mathrm{~g} / \mathrm{kg}$ of Gmelina arborea leaf meal had the highest mean percentage weight gain (198.78\%) followed by the $50 \mathrm{~g} / \mathrm{Kg}(179.07 \%)$. Then those fed with $150 \mathrm{~g} / \mathrm{kg}$ of $\mathrm{Gmelina}$ arborea leaf meal) had the least percentage weight gain (165.51\%). This shows that the favourable attributes of spices can be masked when they are used in large proportions where the effect of inherent antinutritional factors like tannin and saponin become pronounced(25).

Specific growth rate (SGR) 
From table 4, there is a significant difference in the mean specific growth rate $(\mathrm{P}<0.05)$ of quails fed with varying levels of Gmelina arborea. Quails fed with $0 \mathrm{~g} / \mathrm{kg}$ of Gmelina arborea leaf meal had the highest specific growth rate of 0.184 followed by the quails fed with $50 \mathrm{~g} / \mathrm{kg}$ and $100 \mathrm{~g} / \mathrm{Kg}$ of Gmelinaarborea leaf meal with SGR of 0.178 and 0.172 respectively. Then those fed with $150 \mathrm{~g} / \mathrm{kg}$ of Gmelina arborea leaf meal had the lowest SGR of 0.167.The higher values in the mean SGR of those fed with $0 \mathrm{~g} / \mathrm{kg}$ (A) compared to other treatments $50 \mathrm{~g} / \mathrm{kg}$ (B), $100 \mathrm{~g} / \mathrm{kg}(\mathrm{C}), 150 \mathrm{~g} / \mathrm{kg}$ (D), of Gmelinabarborea leaf meal is understandable because these antinutritional factors have been reported to affect utilization of nutrients and depress growth(26).

\section{Feed intake}

From Table 4, feed consumption during the research ranged from $76.99 \mathrm{~g} / q u a i l / w k-140.55 \mathrm{~g} /$ quail/wk which is lower than the values observed, which were $79.19 \mathrm{~g} /$ quail/wk $-154.70 \mathrm{~g} /$ quail/wk(27).There is significant $(\mathrm{P}<0.05)$ difference in the mean feed intake. This could be as a result of higher crude fiber content of the dietary treatment. This agreed with the findings that reported that birds on high fibre diet tend to consume more of the feed to meet their requirement for growth and development (28 and 29). However, the findings disagreed with the report which stated that high fibre diet reduces hunger, thereby reducing feed intake(30).

\section{Feed Conversion Ratio (FCR)}

There is significant $(\mathrm{P}<0.05)$ difference in the mean feed conversion ratio $(\mathrm{FCR})$. This study agrees with the report of dietary treatment significant $(\mathrm{P}<0.05)$ effect on feed conversion ratio on quails fed with soaked sweet orange peel meal (SOPM) as the lowest feed conversion ratio of the control diet (C) showed that this diet was better than SOPM based diets(31). So the inclusion levels of Gmelin aarborea leaf meal had effect on the utilization of diets by reducing absorption of nutrients(31). The study concurs with the observations which stated that the lower the food conversion ratio, the better the food conversion efficiency of each experimental diet $(\mathbf{2 8}, \mathbf{3 2}$ and $\mathbf{3 3})$. Feed conversion ratio is a direct indication of how best the feed given to birds was turned to meat. However, the significant better food conversion ratio of treatment $0 \mathrm{~g} / \mathrm{kg}(\mathrm{C})$ and $50 \mathrm{~g} / \mathrm{kg}\left(\mathrm{T}_{1}\right)$ dietary levels of Gmelina arborea leaf meal compared to other treatment groups may be attributed to the higher weight gain values of the birds on this diet which is line with the observation that reported lower and better feed conversion ratio on birds with higher weight gain values(25).

\section{Feed efficiency ratio (FER)}

There is significant $(\mathrm{P}<0.05)$ difference in the mean Feed efficiency ratio $(\mathrm{FER})$. The finding is in contrast with the report of $(\mathrm{P}>$ $0.05)$ no significant influence of dietary protein levels on feed efficiency when laying quails were fed diets with different protein levels (14 and 15). But it has been documented that the nutritive quality of a feedstuff is measured by its ability to release nutrients for maintenance and productivity of the animals (34).

\section{Protein efficiency ratio (PER)}

There is significant $(\mathrm{P}<0.05)$ difference in the mean Protein efficiency ratio (PER). This is in agreement with the finding that reported significant $(\mathrm{P}<0.05)$ difference on protein intake recorded by different dietary treatment $(\mathbf{3 5}$ and 36$)$.

\section{CONCLUSION}

Studies of inclusion of leaf meals in the formulation of livestock feed as non- conventional feeding materials are increasing. The data obtained from the present study shows that Gmelina arborea leaf meal is one of the trees with significant number and amounts of phytochemicals. Hence, the presence of rich secondary metabolite concentration can apparently make the plant a good source of nutrients. There was no observable negative effect on the health status of quails fed with the varying levels of Gmelina arborea leaf meal indicating healthy effect of the Gmelina arborea leaf meal for the birds since no medication was used throughout the period of study. The $50 \mathrm{~g} / \mathrm{kg}$ inclusion level of Gmelina arborea leaf meal is comparable with $0 \mathrm{~g} / \mathrm{kg}(\mathrm{Control})$ diet, it can adequately be added in quails' nutrition at the level without any negative effect on growth performance as there was significant weight gain for certain duration. Though, all the inclusion levels of Gmelina arborea leaf meal resulted in weight loss proving that Gmelina arborea leaf meal is dosage and time dependent. Conclusively, the performance of birds in this present study suggested that $50 \mathrm{~g} / \mathrm{kg}$ of Gmelina arborea leaf meal could be successfully included in quails' diets for certain period without any adverse effect.

\section{References}

[1] Tuleun, C. D and Dashe, N. A (2010).Effect of dietary levels of toasted mucuna seed meal (TMSM) on the performance and egg quality parameters of laying Japanese quail (Coturnixcoturnix japonica). International Journal Of Poultry Science. 9(12): 1092 - 1096.

[2] Nworgu, F. C, Oduola, O.A, Alikwe, P.C and Ojo, S. J. (2012).Effect of basil (Ocimu gratissimum) leaf supplement on initiation of egg laying and egg quality parameters of growing pullets.Journals of Food, Agriculture and Environs, 10(2): 337 - 342.

[3] Esonu BO, Iheukwumere FC, Iwuji TC, Akanu N, Nwugo OH (2003). Evaluation of Microdermis puberulaleaf meal as ingredient in broiler starter diets.Nig. J. Anim. Prop., 30: 3-8.

[4] Fashina OE, Ologhogbo AD, Adeniran GA, Ayoade GO, Adeyemi OA, Olayode G, OlubanjoOO (2004). Toxicological assessment of Vernoniaamygdalianaleaf meal in the nutrition of broiler starter chicks.Nig. J. Anim. Prop. 31: 3-11.

[5] OkagbareG.O, Akpodiete O. Esiekpe and OnagbesanO.M (2004). Evaluation of Gmelinaarborealeaves supplemented with grasses (pennisetum purpureum) as feed for west African dwarf goats. Trop. Health Anim. Prod., :593-598. 
[6] Amata IA (2010b). Nutrtive value of the leaves of Myrianthusarboreus: A browse plant. Int. J. Agric. Res.

Res. 576-581.

[7] Amata, I. A. and Lebari, T. (2011). Comparative evaluation of the nutrient profile of four selected browse plants in the tropics, recommended for use as non-conventional livestock feeding materials. African Journal of Biotechnology Vol. (64), pp. 14230-14233.

[8] Momoh, M. O., Gambo, D. and Dim, I. N. (2014). Genetic parameter of growth, body and egg traits in Japanese quails (Coturnixcoturnix japonica) reared in southern of Nigeria. J. Applied Bioscience 79: 6947-6954.

[9] Deyab M S D El-Saidy\& Amal S Saad (2011). Effects of partial and complete replacement of soybean meal with cottonseed meal on growth, feed utilization and haematological indexes for mono-sex male Nile tilapia, Oreochromisniloticus (L.) fingerlings Aquaculture Research, Vol. (42); 351-359.

[10] Okeke, J. J and Magbo, T, C (2013). Comparative of growth performance of grasscutter fed with Diverse Food Stuff in captivity. International Journal of Advanced Biological Research, 3 (1) Pp 85- 89.

[11] A.O.A.C, (1990). Association of Official Analytical Chemists.16 ${ }^{\text {th }}$ Ed. Washington D. C. USA.

[12] Harbone, J.B. (1998). Methods of extraction and isolation 'phytochemical methods'.3rd edition. Chapman and

Hall, London, pp: $60-66$.

[13] SPSS (2007). Statistical package for Socail Science. Release 17.0.User Manual.Microsoft Corp; U.S.A.

[14] Murakami A. E, MoraesV.M.B, De Arikki J, Junqueira O. M, Kronka S. Don (1993b) Levels of protein and energy in diets of growing Japanese quail (Coturnixcoturnix japonica). Revista de SocidadeBrasleira de Zootechnia, 22(4); 541551.

[15] Babangida, S and Ubosi, C. O (2006). Effect of varying dietary protein levels on the performance of Japanese Quail (Coturnix coturnix japonica) in a semi arid environment. Nigeria Journal of Animal Production, 33(1): 45 52.

[16] NRC, (1994). Nutrient Requirement of Poultry. National Research Council. Washington, USA, Pp 41 - 54.

[17] Bawa, G. S, Lombin, L. H, Karsin, P, Payi, E and Shamaki, D (2011). Responses of Japanese quails to varying dietary protein levels in the tropics.Nigeria Journal Animal Production.38(1): 43 - 54.

[18] Aye P.A (2016) Comparative nutritive value of moringaoleifera, tithoniadiversifoliaand gmelinaarborea leaf meals. American journal of food and nutrition/ajfn.6.1.23.32.

[19] Hunt, S, Groff, I. L and Holbrook, J (1980). Nutrition, Principle and Chemical practice. John Wiley and Sons. NewYork. USA. Pp 49 52, 459 462.

[20] Taiwo, A. A, Adejuyigbe, A. D, Adebowole, A. E, Oshotan, J. S and David, O. O (2005). Performance and Nutrient Digestibility of Weaned fed forages supplemented with concentrate. Nigeria Journal Animal Productio, $32(1)$ : 74 - 78.

[21] Osakwe, L.L. (2003). Effect of dried Morindalucida supplementation on nitrogen and energy retention of sheep fed basal hay diet. Proceeding of the 28th Animal Conference of the Nigerian Society for Animal Production, Institute of Agricultural Research and Training, Obafemi Awolowo University,Ibadan, Vol 28, 263-265.

[22] Okpara, O., Akpodiete, O.J. And Okagbare, G.O, (2016). Nutritional Appraisal of Processed Gmelina arborea Leaves as Feed of Livestock. Journal of Agriculture \& Food Environment Vol. 3 (1) 61

[23] Iswarya S, Sridevi M, Mayavel A (2017). Comparative Study on Phytochemical and Antioxidant Properties of Gmelina arborea Roxb.from four Different Geographical Regions. International Journal of Pharmaceutical and Clinical Research; 9(4): 275-280

[24] Nieman, D. C, Butterworth, D. E, Nieman, C. N (1992).Nutrition.W M C. Brown Publishers, Dubuque.

[25] Odoemelam, V. U, Nwaogu, K. O, Ukachukwu, S. N, Etuk, E. B, Etuk, I. F, Aladi, N. O and Ogbuewu, I. P (2013). Growth response, Carcass quality and Organoleptic assessment of broiler chicken fed Ocimumgratissimum leaf supplemented diets. International Journal of Agricultural Rural Development, 16(2); 1521 - 1528.

[26] Odoemelam, V. U, Nwaogu, K. O, Ukachukwu, S. N, Esonu, B.O, Okoli, I. C, Etuk, E. B, Ndelekwute, E. K, Etuk, I. F, Ogbuewu, I.P and Kadurumba, O. E (2012). Performance of Broiler chicken fed Ocimumgratissimum leaf supplemented diets. Proceedings $6^{\text {th }}$ Annual Conference Nigeria Science for indigeneous knowledge and Development (NSIKAD). June $5^{\text {th }}-7^{\text {th }}$. Umudike. Pp $15-16$.

[27] Anggaeni, N, Farjallah, A \&Astuti, D. A (2016). Blood profile of Quails (Coturnixcoturnix japonica) fed Ration containing Silkworm (Bombyxmori) powder extract. Media Peternakan, 39(1):1-8.

[28] Jumaa, B.J., Dafalla, M.M., Bushara, I and Amin, M.H.H. (2014). Effects of inclusion of different levels of watermelon bug meal in broiler diets on feed intake, body weight changes and feed conversion ratio. Global Journal of Animal Scientific Research.2(1), 76- 85

[29] Hassan, A.A. (2009). The effect of replacing graded levels of fish meal with grasshopper meal in broiler starter diet. PAT 5(1), $30-38$

[30] Nielsen, B.L. (2011). Promotion of insoluble fibre in the diet effects, behavior and hunger in broiler breeders growing at similar rates. Animal.5(8), $1247-1258$

[31] Guluwa, L. Y, Madaki, Y. A, Machido, H, Damtayi, R. D and Kulokom, S (2014). Growth performance and carcass evaluation of Quails fed graded levels of water soaked Sweet Orange Peel Meal (SOPM). Advances in Life Sciences and Technology, 20: 111-116

[32] Okah, U and Onwujiariri, E.B (2012). Performance of finisher broiler chickens fed maggot meal as a replacement for fish meal. Journal of Agricultural Technology.8(2), 471 - 477.

[33] Dube, S and Tariro, M. (2014). Effect of including some insects as feed supplement on broilers reared in Zimbabwe. International Journal of Poultry Science.13(1), 42- 46. 
[34] Oluyemi, J.A and Roberts, F.A (2000). Poultry production in warm-wet climate. Spectrum Books Ltd, Ibadan, Nigeria.

[35] Tuleun C. D, Adenkola, A. Y. and Afele T (2011). Effect of dietary ascorbic acid supplementation on the performance of Japanese (Coturnix coturnix japonica) quails in a tropical environment. Journal of Animal and Plant Science, Vol 10; $1268-1275$.

[36] Tuleun, C. D, Adenkola, and Yenle, F. G. (2013). Performance and Erythrocytes osmotic membrane stability of Japanese Quail (Coturnix coturnix japonica) fed varying dietary protein levels in a hot humid tropics. Agriculture and Biology Journal of North America.4.1.6.13. 